$725,680,625,610,420$

IV. 本法の利点

$\mu$-dichloro ( $\pi$-benzene)ruthenium (II) [1]の合成に関しては, Winkhaus らの報告 ${ }^{3)}$ があるが，詳細については記 載されていない。脱水エタノールを用い, Winkhaus らが行なった条件において合成した場合, 得られた沈殿物〔1a〕 は黒かっ色で，元素分析值は計算值にあわず再現性もなかった。ただし〔2】の合成には差支えない。一方，含水エタノ 一ルを用いる本法によって得られた沈殿物〔1b〕は茶色の固体で純度もよかった。元素分析值の一例をあげると，

[1a]: C $24.51 \%, \mathrm{H} 2.69 \%, \mathrm{Cl} 30.19 \%$ 。

[1b]: C $27.45 \%, \mathrm{H} 2.29 \%, \mathrm{Cl} 28.46 \%$ 。

Calcd. for $\left(\mathrm{C}_{6} \mathrm{H}_{6} \mathrm{RuCl}_{2}\right)_{\mathrm{n}}: \mathrm{C} 28.82 \%, \mathrm{H} 2.42 \%, \mathrm{Cl} 28.35 \%$ 。

DMSO 以外の溶媒に不溶なので再結晶などの精製は不可能である。なお〔1a〕と〔1b〕はまったく同一の IR, NMR スペクトルを与えた。

〔1]の製法は，置換シクロヘキサジエンにも適用できるが，得られる沈殿物は一般に $\left(\mathrm{ArRuCl}_{2}\right)_{\mathrm{n}}\left(\mathrm{RuCl}_{2}\right)_{\mathrm{m}}(\mathrm{Ar}=$ 芳香族化合物）の形となり，置換基が大きくなると $\mathrm{m} / \mathrm{n}$ の值が大きくなる傾向がある。

DMSO 配位錯体〔2〕は新化合物であり，他の合成法は報告されていない。

\title{
引用文献
}

1) A.J. Birch, J. Chem. Soc. 1946593

2) I. Ogata, R. Iwata, Y. Ikeda, Tetrahedron Letters 19703011

3) G. Winkhaus, H. Singer, J. Organometal. Chem. 7487 (1967)

\section{6-Methyl-1, 2-diphenyl-2, 3-dihydro-4-pyridone}

提案者 杉山 登, 山本 忠, 鹿島長次

(東京教育大学理学部)

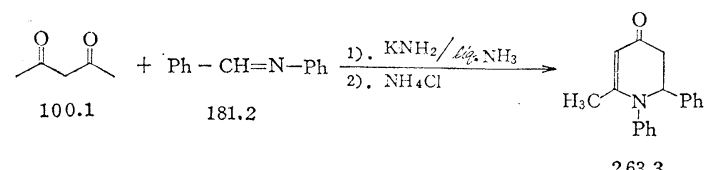

\section{I. 製 法}

$500 \mathrm{ml}$ の三っロフラスコの中央の口に気密カキマゼ装置を取り付け，他の一つの口に導入管を接続しておく。三っ ロフラスコ（注意 1) をドライアイスーアセトンで泠却しながら，導入管から乾燥したアンモニアガスを通じ，約 300 $\mathrm{m} l$ の液体アンモニアを凝縮させる。これに約 $0.2 \mathrm{~g}$ の金属カリウムと触媒量の塩化鉄 (III) を加え，カリウムの青色 が消えるまでかきまぜる1)。つぎにこの無色の液体アンモニア溶液（注意 2 ) に $5.85 \mathrm{~g}(0.15 \mathrm{~g}$ atom）の金属カリウム を加え，青色が消えるまで 1.5 2 時間かきまぜカリウムアミドのアンモニア溶液をつくる。この溶液に $5.0 \mathrm{~g}(0.05$ モル）の acetylacetone を $30 \mathrm{~m} l$ の無水エーテルに溶かした溶液を加え 1 時間かきまぜ，つぎに $9.05 \mathrm{~g}(0.05 \mathrm{~mol})$ の benzylidenaniline を加えさらに 2 時間かきまぜる。

過剩の塩化アンモニウム $(10.7 \mathrm{~g}, 0.2 \mathrm{~mol})$ （注意 3 ) を加えて中和したのち, 水浴上でアンモニアを留去し, 残 留物に $100 \mathrm{ml}$ のエーテル, $150 \mathrm{~m} l$ の $2 \mathrm{~N}$-希塩酸を加え, エーテル層を分け, 水層をエーテル $150 \mathrm{~m} l$ で抽出する。 乾燥後減圧濃縮し, シリカゲル (Merck 7729, $0.08 \mathrm{~mm}$ ) カラムクロマトグラフィーで, ベンゼン/酶酸エチル $(4: 1 \mathrm{v} / \mathrm{v})$ 混合溶媒で展開分離し，濃縮後四塩化炭素から再結晶すると無色ないし淡黄色の針状結晶 $\mathrm{mp} 84 \sim 85^{\circ} \mathrm{C}$ が得られる。 （収量9.85 8.55g (75 65\%)。

\section{II. 注 意 事項}

(1) 三ッロフラスコ内はアンモニアガスを通じるまえに窒素ガスで置換しておく。

(2) 窒素気流下で行なう。

(3) 固体の塩化アンモニウムを直接加える。

\section{III. 性質}

$\mathrm{mp} 84 \sim 85^{\circ} \mathrm{C}$ 。アルコール，ベンゼン，アセトン，クロロホルムに易溶。n-ヘキサン，水に難溶。

$\mathrm{UV}(\underset{\max }{\mathrm{E}+\mathrm{OH}}): 327 \mathrm{~nm}(\varepsilon$ 18000)。

$\operatorname{IR}(\mathrm{KBr}): 1645,1560 \mathrm{~cm}^{-1}$ 。

$\operatorname{NMR}\left(\tau, \mathrm{CCl}_{4}\right): 8.20(\mathrm{~s}, 3 \mathrm{H}), 6.88 \sim 7.62(\mathrm{~m}, 2 \mathrm{H}), 5.10(\mathrm{t}, 1 \mathrm{H}), 4.96(\mathrm{~s}, 1 \mathrm{H}), 2.85 \sim 2.92(\mathrm{~m}, 10 \mathrm{H})$ 。 


\section{IV. 試 験 法}

6-methyl-1,2-diphenyl-2,3-dihydro-4-pyridone をシリカゲルの薄層クロマトグラフィを行ない，この薄層に塩化 鉄（III）のメタノール溶液を噴霧すると, メタノール溶液の濃度がうすい場合は $\beta$-ジケトン類と同様茶〜紫色汇呈色 するが，濃くしたものを噴霧するかまたは薄層を加温すると緑色を呈する。他のジヒドロピりドンも同様の呈色をする ので検出することができる。ただし窒素原子に置換基をもたないジヒドロピリドンは茶色を呈するのみである。

\section{V. 本法の利点}

従来，ジヒドロピリドン類の一般合成法としては，相当する $\gamma$-ピリドンの接触還元が知られているが2)，この方法は 反応を制御することが困難である。本法はこれとは異なり $\beta$-ジケトンとシッフ塩基とから高収率で直接合成すること ができるぶ。シシフ塩基として benzaldazine を用いて反応を行ない，ついで接触還元を行なうと，窒素原子に置換基を もたないジヒドロピリドンの合成も可能である4)。

\section{引用文献}

1) C.R. Hauser, T.M. Harris, J. Am. Chem. Soc. 806360 (1958)

2) J. Hebky, J. Kejha, Chem. Listy. 50834 (1956)

3) N. Sugiyama, M. Yamamoto, C. Kashima, Bull. Chem. Soc. Japan 421357 (1969)

4) N. Sugiyama, M. Yamamoto, C. Kashima, ibid. 43901 (1970)

\section{Tri-n-butylborane}

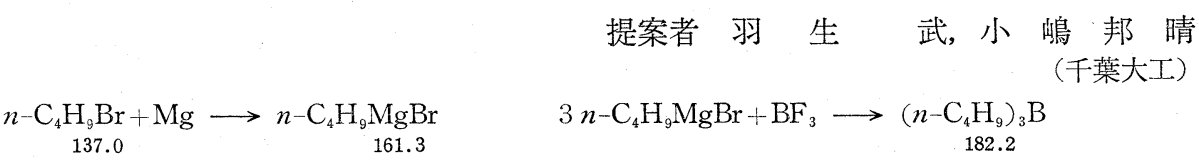

I. 製法

内容 $1 l$ の三っロフラスコにカキマゼ器, 泠却器, $200 \mathrm{~m} l$ 滴下ロートをつけ, 上先端に塩化カルシウム管をつけ 2 ～3 日放置して装置内を十分乾燥する。うぎにこの中に乾燥した金属マグネシウム片 $24 \mathrm{~g}(1 \mathrm{atom})$ を入れ，ヨードの 結晶片を少量加えて表面を腐触する。金属ナトリウムで脱水したのち蒸留したエーテル $500 \mathrm{ml}$ を加えて充分に浸し, ついで滴下漏斗より乾燥エーテル $100 \mathrm{~m} l$ で希釈した $n$-butyl bromide $38.4 \mathrm{~g}(1.1 \mathrm{~mol}$ ) 徐々に滴下する（注意 1 )。 1〜1.5 時間後に金属マグネシウムが完全に溶解したのち boron trifluoride-ether complex $148 \mathrm{~g}\left(47 \% \mathrm{BF}_{3} ; 1 / 3 \mathrm{~mol}\right)$ を同容積の乾燥エーテルで希釈して滴下する。滴下終了後 $35 \sim 40^{\circ} \mathrm{C}$ で還流を 2 時間続けた後反応を止め一夜放置する (注意 2 )。沈殿物を含む反応混合物よりエーテル層を分離して（注意 3 ）窒素雾囲気下のドライボックス中で隇圧蒸 留して, bp 100 $102^{\circ} \mathrm{C} / 17 \mathrm{mmHg}$ の留分 $41 \mathrm{~g}$ (収率 70\%) を得る（注意 4)。これはさらにドライボックス中で減圧精 留し, アンプルに入れて保存する(注意 5 )。

\section{II. 注 意 事 項}

(1) $n$-butyl bromide のエーテル溶液を最初 $10 \sim 15 \mathrm{~m} l$ 加えて反応を開始させ，おだやかな還流がはじまったらさ らに残りの $n$-butyl bromide を滴下する。

（2）反応が終ったら酸素に触れないよう汇密せんして放置する。

（3）反応混合物を蒸留フラスコにうつし変えるときになるべく酸素に触れないようにデカンテーションして分離す る。

(4) 減圧蒸留が終ったのちに窒素ガスを送って常圧にする。

（5）生成物は空気中で激しく反応して発煙する。ときには発火する危険があるので咥素気流中で操作する。

\section{III. 性質}

無色の液体で空気中で発煙して分解する。

bp $100 \sim 102^{\circ} \mathrm{C} / 17 \mathrm{mmHg}, n_{\mathrm{D}}^{25} 1.4285$, IR : $1460 \mathrm{~cm}^{-1}(\equiv \mathrm{C}-\mathrm{B}=)$ 。

\section{IV. 本法の利点}

本合成法は文献1,3) に準拠したものであるが，本改良法によると副生物が少ないので収率が上がる利点がある。 引用文献

1) A.T. Whatley, R.N. Pease, J. Am. Chem. Soc. 76835 (1954)

2) Callery Chemical Company, Technical Bulletin C-310 (1959)

3）増原英一，小鴆邦晴，木村正，歯材研報 2369 (1962) 